\title{
Patterns of paralytic shellfish toxicity in the St. Lawrence region in relationship with the abundance and distribution of Alexandrium tamarense*
}

\author{
DOLORS BLASCO ${ }^{1}$, MAURICE LEVASSEUR ${ }^{2}$, ESTHER BONNEAU ${ }^{3}$, \\ ROGER GELINAS ${ }^{4}$ and T.T. PACKARD ${ }^{1}$ \\ ${ }^{1}$ Institut Ciències del Mar, CSIC, Passeig Marítim de Barceloneta 37-49, Barcelona, 08003, Spain. \\ E-mail: blasco@icm.csic.es \\ 2 Département de Biologie, Université Laval, Québec, Québec, Canada, G1K 7P4. \\ ${ }^{3}$ Department of Fisheries and Oceans, Maurice Lamontagne Institute, P.O. Box 1000, Mont-Joli, Québec, Canada, G5H $3 Z 4$. \\ ${ }^{4}$ Department of Fisheries and Oceans, Inspection Branch, Québec, Québec, Canada.
}

SUMMARY: Shellfish toxin data from 11 years and Alexandrium tamarense abundance during 6 of those years are analysed. Comparison of PSP toxicity in Mytilus edulis with PSP toxicity in Mya arenaria shows a significant correlation $\left(\mathrm{r}^{2}=0.61\right)$, with $M$. edulis being five times more toxic. The results support using M. edulis as a sentinel species for shellfish toxicity in the St. Lawrence region. High interannual variability was found in the PSP and A. tamarense data, but no trends were manifest. Correlation analysis revealed clearly defined geographical station groups. These groups were characterised by seasonal distributions and outbreak times, and were associated with the surface seawater circulation. The results indicate blooms spreading from the open Gulf, upstream toward the Estuary. Since the spring bloom also spreads upstream, we hypothesise that the A. tamarense bloom is just one of the steps in the traditional phytoplankton succession diatoms-dinoflagellates-small flagellates, which is controlled by the classic oceanographic processes of nutrient depletion and water column stratification. A. tamarense distribution over the entire sampled area was similar to the PSP toxicity in M. edulis. In 1993, $59 \%$ of PSP variability was explained by A. tamarense. Furthermore, mussel toxin rises with increasing A. tamarense concentration. Shellfish contamination starts as soon as A. tamarense is present in the water. In addition, detoxification starts when $A$. tamarense decreases below the level of detection. However, the most important finding of this study is that only $1000 \mathrm{~A}$. tamarense cells per litre are sufficient to raise the toxin in the mussels to the level ( $80 \mu \mathrm{g} \mathrm{STX} \mathrm{eq/100} \mathrm{g} \mathrm{tissue)} \mathrm{at}$ which the closure of shellfish harvesting activities is obligatory.

Key words: red tides, harmful algal blooms, dinoflagellate, phytoplankton, PSP, mussels, Mytilus edulis, Mya arenaria.

RESUMEN: PAUTAS DE INTOXICACIÓN PARALÍTICA DE MOLUSCOS EN LA REGIÓN CANADIENSE DEL Río SAN LORENZO: RELACIÓN CON ABUNDANCIA Y DISTRIBUCIÓN DE ALEXANDRIUM TAMARENSE. - Once años de datos de toxina de moluscos y seis años de abundancia de Alexandrium tamarense han sido analizados. La comparación de la toxicidad PSP en Mytilus edulis con la toxicidad PSP en Mya arenaria pone en evidencia una correlación (r2=0.61), siendo M. edulis cinco veces más tóxico. Los resultados sustentan la utilización de M. edulis como especia centinela de la toxicidad de moluscos en la región del San Lorenzo. Se ha encontrado una alta variabilidad interanual en los datos de PSP y de A.tamerense, pero sin un claro patrón reconocible. Análisis de correlaciones reveló claramente la existencia de grupos geográficos de estaciones. Estos grupos se caracterizaban por su semejanza en la distribución estacional y la fecha de aparición de los máximos, y estaban asociados con la circulación superficial del agua del mar. Los resultados indican que la floración de A. tamarense prolifera desde Golfo abierto hacia el estuario. Ya que la floración de fitoplancton primaveral en esta región también se desplaza en esta dirección, presentamos la hipótesis que la floración de A. tamarense es simplemente una de las etapas de la sucesión fitoplanctónica general en el Estuario: diatomeas, dinoflageladas, microflageladas. Evolución controlada por el proceso oceanográfico clásico de empobrecimiento de nutrientes y estratificación de la columna de agua. La distribución de A. tamarense en toda el área muestreada es muy parecida a la de la toxicidad PSP de M. edulis. En 1993, 59\% de la variabilidad del PSP es 
explicada por A. tamarense. Además la toxicidad de los mejillones, aumenta proporcionalmente al aumentar la concentración de $A$. tamarense. También la detoxificación de los mejillones empieza cuando A tamarense decrece por debajo del nivel de detección. Quizá el hallazgo más importante de este estudio es que solo una concentración de A. tamarense de 1000 células por litro es suficiente para que la toxicidad de los mejillones alcance $80 \mu \mathrm{g}$ STX eq/100 g tejido, nivel al que la prohibición de recogida de moluscos es internacionalmente obligatoria.

Palabras clave: fitoplancton, dinoflageladas, Mya arenaria, Mytilus edulis, PSP, intoxicación paralítica de moluscos, mejillones, floración de algas.

\section{INTRODUCTION}

Paralytic shellfish poisoning (PSP) outbreaks in the Estuary and the Gulf of St. Lawrence have been known since 1949 (Medcof et al., 1966; Beaulieu and Menard, 1985). The geographical extent of the Quebec coast affected by these outbreaks and the frequency and level of the shellfish intoxication are of similar magnitude to those of the Gulf of Maine (Prakash et al., 1971). However, while PSP outbreaks off the New England coast have been extensively studied (Hurst and Gilfillan, 1977; Hurst and Yentsch 1981; Yentsch and Inze 1981; Anderson et al., 1982; White 1987; Shumway et al., 1988; Martin and Richard 1996; Anderson 1997), the PSP outbreaks off the St. Lawrence coast have not been studied as extensively.

In 1952, the Ministère des Pèches et de l'Agriculture du Québec started monitoring shellfish as potential vectors for PSP and instituted periods of mandatory closure of shell fishing areas in the St. Lawrence region. Since then, clam and mussel beds along more than $800 \mathrm{~km}$ of the Quebec coast have been closed for harvesting for varying periods, on a nearly annual basis. At the same time, studies were conducted to understand the development and distribution of the toxic dinoflagellate, Alexandrium tamarense in the region (Therriault et al., 1985; Cembella and Therriault 1989; Larocque and Cembella 1990). These studies showed that blooms of the motile stage of the A. tamarense are a recurrent phenomenon and that its resting cysts are present all along the coast (Cembella et al., 1988a; Turgeon et al., 1990). Analysis of the Alexandrium cells and cysts showed that the indigenous population contained high concentrations of PSP toxins (Cembella et al., 1988b). Tentative hypotheses were proposed concerning the relationship between the distribution of Alexandrium and the environmental variables, as well as the possible impact of the organism on the entire ecosystem (Gosselin et al., 1989; Desbiens et al., 1990; Robineau et al., 1991; Levasseur et al., 1994; Desbiens and Cembella 1995; Turriff et al., 1995). In 1984, the Department of Fisheries and
Oceans of Canada, Inspection Branch, Quebec, assumed responsibility for shellfish monitoring and began to provide more precise information about the temporal and spatial distribution of toxicity along the entire coast. In autumn 1989, researchers of the Department of Fisheries and Oceans at the Institute Maurice-Lamontagne initiated an extensive phytoplankton monitoring programme of the entire Quebec coast.

In this paper, the shellfish toxin data from 11 years of surveys, along with the A.tamarense results of abundance and distribution during 6 years of the monitoring programme (Blasco et al., 1998), are analysed. Comparison of rates of intoxication and detoxification of clams and mussels in the field were made and the relationship between Alexandrium and PSP toxicity is explored. The results presented in this paper provide a robust basis for improving future routine monitoring procedures, for defining appropriate policies of using shellfish resources and ultimately for increasing public safety in the St. Lawrence region as well as in other areas.

\section{MATERIALS AND METHODS}

\section{Study area}

The Gulf of St. Lawrence (Fig. 1) is a triangularshaped semi-enclosed sea with an area of 214,000 $\mathrm{km}^{2}$. The main topographic feature is the threepronged Laurentian Channel, the main branch of which is a 300-400 $\mathrm{m}$ deep trough extending from the North Atlantic continental slope, through Cabot Strait, to the head of the Lower St. Lawrence Estuary at Tadoussac (Fig. 1). By contrast, the southern portion of the Gulf is a wide, shallow plateau with depths seldom exceeding $80 \mathrm{~m}$, where the Magdalen Islands are located. The continuous supply of freshwater from the St. Lawrence River and other tributaries maintains an estuarine-like circulation that is highly stratified throughout the year, with an outflow of lighter water near the surface and a penetration of Atlantic water in the deeper layers. The main 


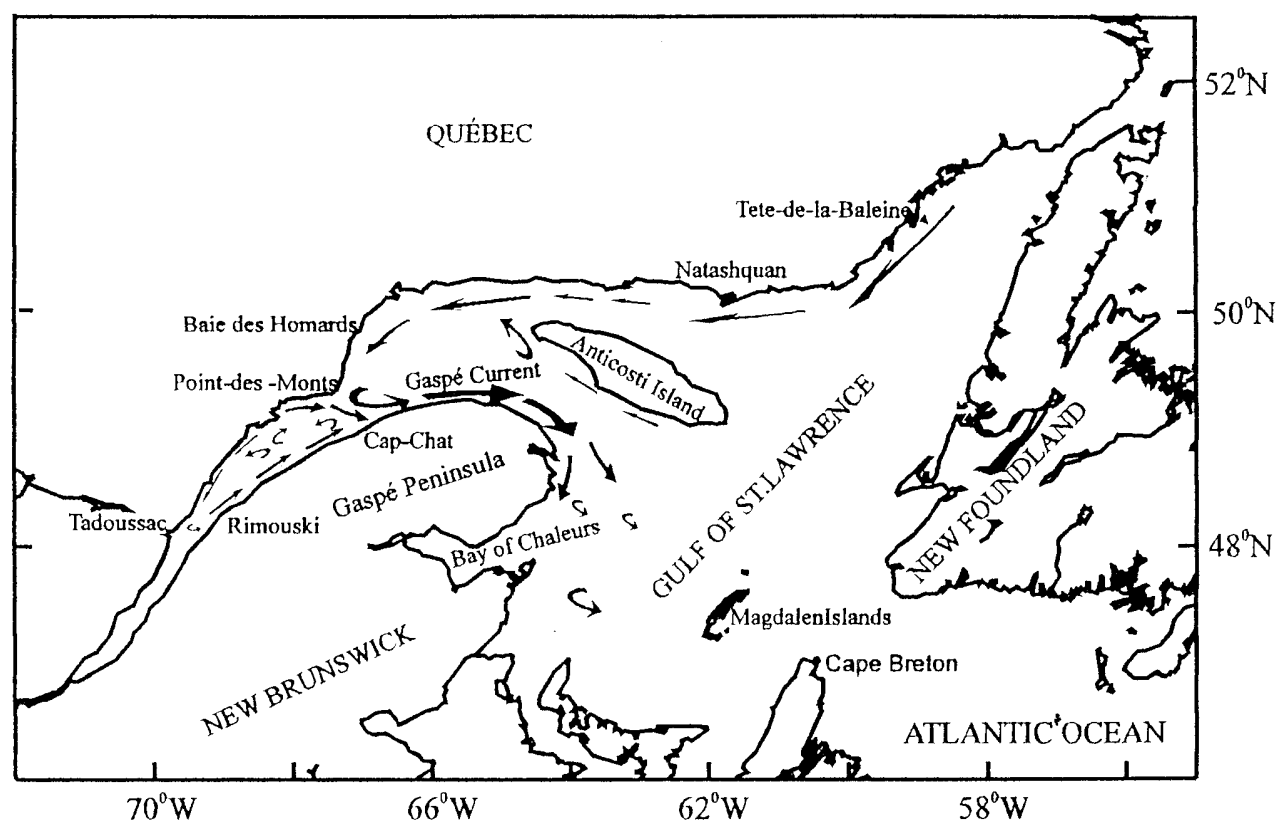

FIG. 1. - Map of the St. Lawrence region, adapted from El-Sabh (1979) and Koutikonsky (1991), with reference to locations mentioned in the text. Arrows refer to mean pattern of summer surface circulation.

features of the surface circulation pattern are the Gaspé and Cape Breton Currents and the existence of a quasi-permanent anticlockwise gyre west of Anticosti Island. The combination of the unique topography, estuarine circulation, and tidal forcing provides this region with distinct hydrographic and biological features relative to adjacent Atlantic waters.

\section{Shellfish sampling}

Mytilus edulis and/or Mya arenaria were collected for PSP analyses along the north and south shores of the St. Lawrence, in the Baie des Chaleurs, and in a lagoon of the Magdalen Islands, during eleven consecutive years: 1984-1994. Shellfish samples were generally collected on a weekly basis from April to November. Details are presented in Blasco et al. (1998). Shellfish toxicity was measured using the mouse bioassay (Sommer and Meyer, 1937) according to the AOAC Official Method (AOAC 1975). Toxicity is expressed in $\mu \mathrm{g}$ saxitoxin (STX) equivalent per $100 \mathrm{~g}$ of shellfish tissue. The limits of detection for our data here was $20 \mu \mathrm{g}$ of saxitoxin equivalent per $100 \mathrm{~g}$ of tissue.

\section{Phytoplankton sampling}

Plankton samples for determination of $A$. tamarense abundance were collected weekly near the shellfish sampling sites at eleven stations during six consecutive years, 1989-1994. The sampling program for phytoplankton usually started at the end of May and ended at the beginning of November (Blasco et al., 1998). At each station, surface water was collected by bucket. Temperature was measured in-situ with a mercury thermometer and two seawater sub-samples were kept for salinity determination, phytoplankton identification and cell enumeration. The phytoplankton sample was immediately preserved with Lugol-iodine solution. Phytoplankton cells were identified and counted using the Utermöhl technique and a Leitz phase-contrast inverted microscope (Utermöhl, 1931). Statistical analyses of the data were carried out on a Power Macintosh (7600/132) using Data Desk and Systat statistical software. The original data is available in Blasco et al. (1998).

\section{RESULTS}

\section{Relationship between PSP toxicity in Mytilus edulis and Mya arenaria}

The shellfish monitoring programme collected either mussels (M. edulis) or clams (M. arenaria), depending on the market demands in each particular area. However, at some sites (Tadoussac, Ste-Luce, Les Escoumins, Baie-des-Ha!-Ha!, Baie-des- 


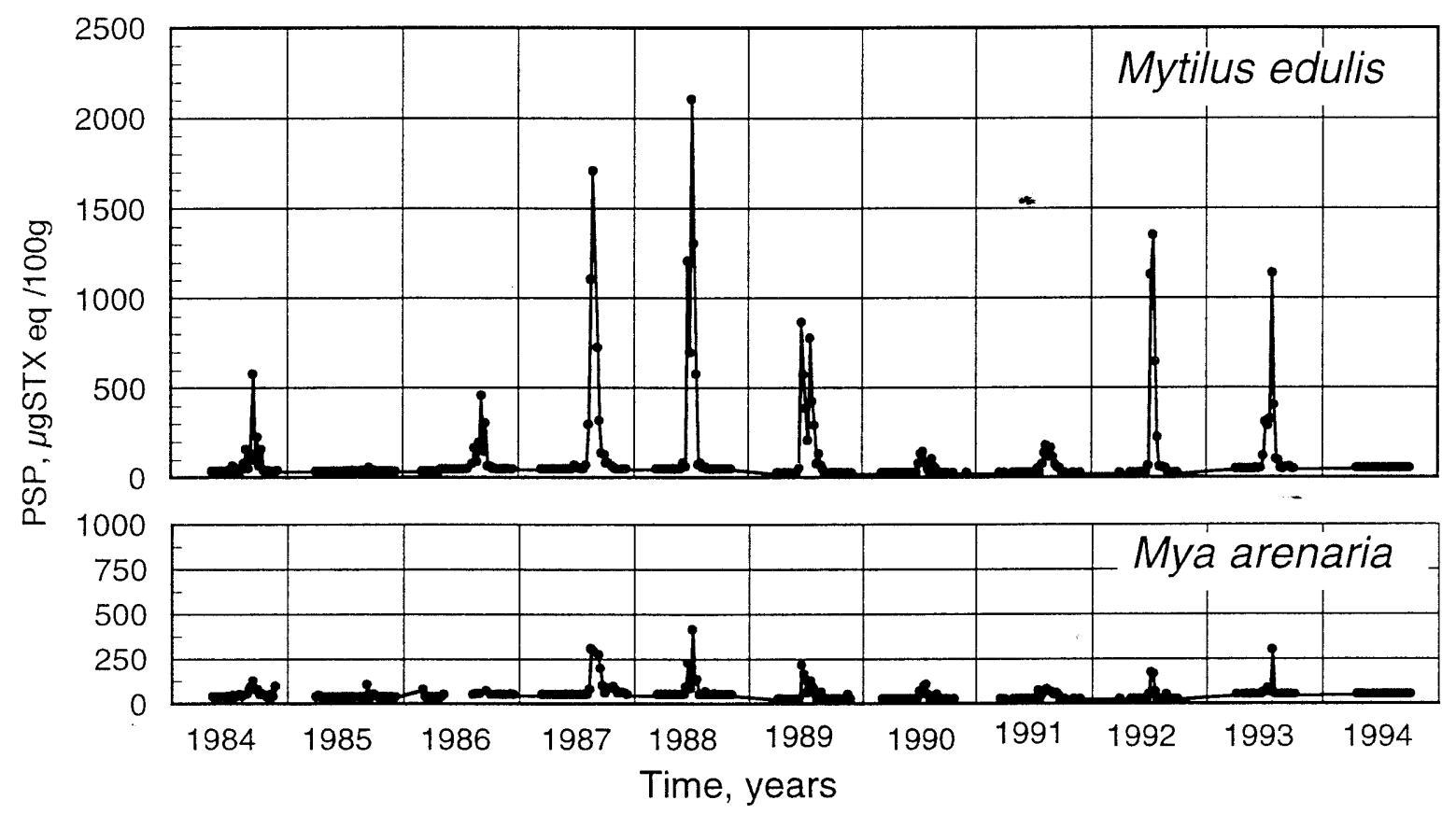

FIG. 2. - Top: Shellfish toxicity in mussels (Mytilus edulis). Bottom: Shellfish toxicity in clams (Mya arenaria). Both time-series are from the Les Escoumins sampling station (Fig. 4).

Homards) and during certain years, the toxin content of both shellfish was analysed. The results from the site Les Escoumins (Fig. 2), from which the longest set of data is available, show clearly that during a given PSP outbreak, the general distribution pattern is similar for both shellfish species, but the magnitude of the toxicity is different for mussels and clams. Regression analysis of these data (Fig. 3 A) shows a significant correlation $\left(\mathrm{r}^{2}=0.61, \mathrm{n}=351\right)$ between the intoxication levels of both organisms, but $M$. edulis is approximately five times more toxic than $M$. arenaria. The similarity in the pattern is further confirmed by comparing the date at which $M$. edulis and $M$. arenaria first attain the regulatory PSP level of $80 \mu \mathrm{g}$ STX eq/100 g tissue, as well as when the toxin level later falls below $80 \mu \mathrm{g}$ STX eq/100 g
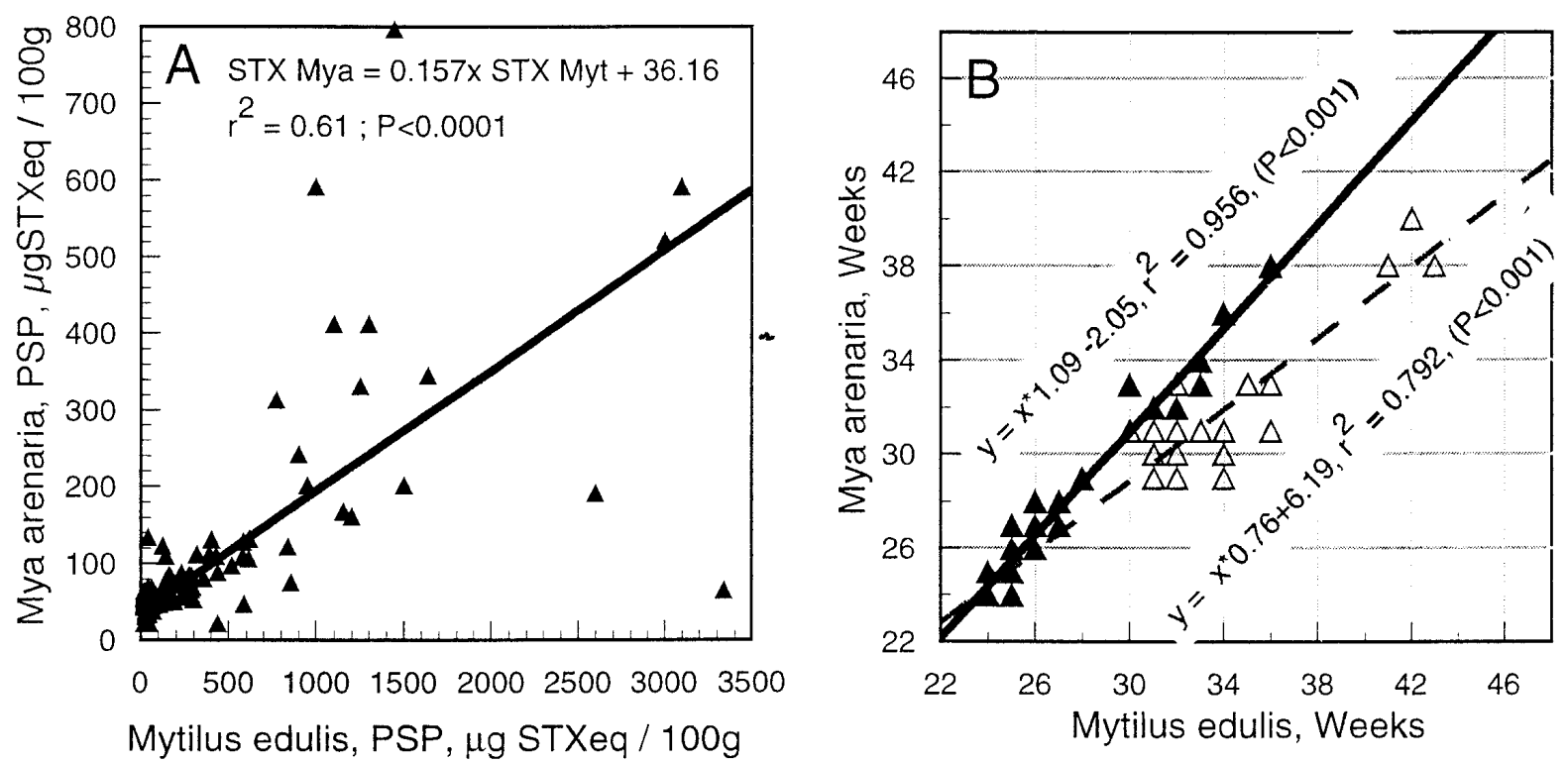

FIG. 3. - A, Relationship between $M$. edulis PSP toxicity and $M$. arenaria PSP toxicity. B, $\mathbf{\Delta}$ : Relationship between the first date at which the PSP in the mussels (Mytilus) and in the clams (Mya) exceeds the regulatory closing level of $80 \mu \mathrm{g}$ STX eq/100g tissue; $\Delta$ : Relationship between the first date at which toxicity of the mussels and clams falls below this level of $80 \mu \mathrm{g}$ STX eq/100g tissue. Weeks refers to the number of weeks from the beginning of the year. 


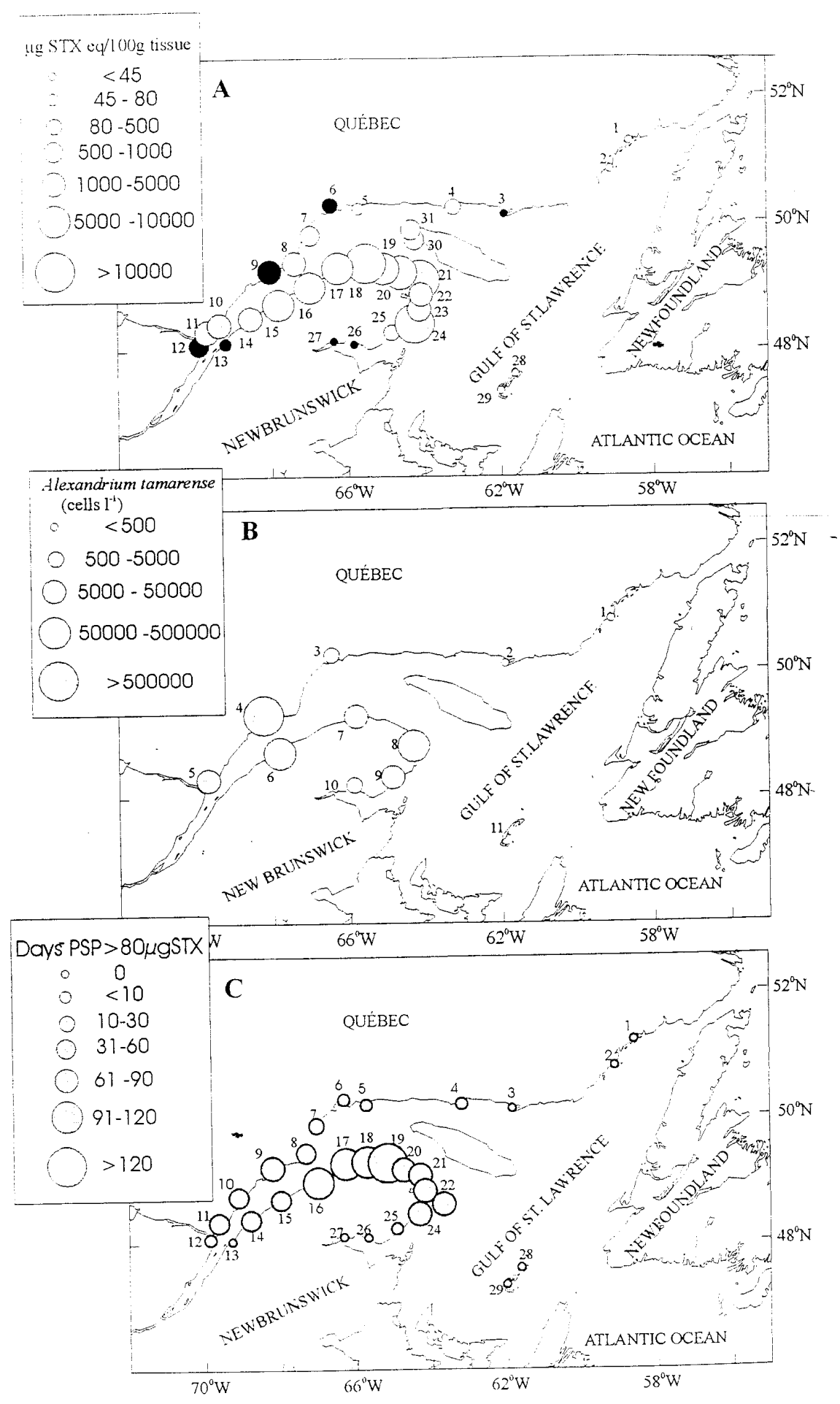

FIG. 4. - A, Maximum PSP-shellfish-toxicity-level observed at each station between 1984 and 1994. Size of the circles indicates the maximum level of toxicity reached by M. edulis at that site. When not available, data from M. arenaria are used (Black circles). PSP sampling stations used for this study: 1, Saint-Augustin; 2, Tête-à-la-Baleine; 3, Havre-Saint-Pierre; 4, Île-du-Havre; 5, Cap Cormoran; 6, RivièreMoisie; 7, Baie-des-Homards; 8, Pointe-des-Monts; 9, Franquelin; 10, Les Escoumins; 11, Tadoussac; 12, Baie-Sainte-Catherine; 13, ÎleVerte; 14, Baie-des-Ha!-Ha!; 15, Sainte-Luce; 16, Cap-Chat; 17, Tourelle; 18, Mont-Louis; 19, Petite-Vallée; 20, Petit-Cap; 21, Cap-desRosiers/Anse-Fugère; 22, Pointe-Saint-Pierre/ Rivière Partage; 23, Percé; 24, Newport/Pabos; 25, Port-Daniel/Gascons; 26, Carleton; 27, Miguasha; 28, Îles-de-la-Madeleine: Grande-Entrée; 29, Îles-de-la-Madeleine: Havre-aux-Maisons; 30, Île d'Anticosti: Port-Meunier; 31, ̂̂le d'Anticosti: Baie-Sainte-Claire. B. Maximum cell densities of A. tamarense found at each of the monitoring stations between 1989 and 1994, and location of the sampling stations: 1, Tête-à-la-Baleine; 2, Natashquan; 3, Sept-Îles; 4, Baie-Comeau; 5, Tadoussac; 6, Ste-Flavie; 7, Mont-Louis; 8, Penouille; 9, Gascons; 10, Carleton; 11, Îles-de-la Madeleine. C, Mean days per season when the shellfish toxicity of the mussels equaled or exceeded the regulatory closing level of $80 \mu \mathrm{g} \mathrm{STX} \mathrm{eq/100} \mathrm{g} \mathrm{per} \mathrm{shellfish} \mathrm{tissue} \mathrm{at} \mathrm{each} \mathrm{station,} \mathrm{from} 1984$ to 1994. 
tissue (Fig. 3B). Regression analysis between toxicity levels of both shellfish species, run on all the existing data, $(n=1199)$, gives a lower correlation $\left(r^{2}=0.47\right)$. However, the regression coefficient of the resulting equation ( $\mu$ STX eq $/ 100 \mathrm{~g}$ tissue in $M y a=$ $38.42+0.11 \mu \mathrm{STX}$ eq/ $100 \mathrm{~g}$ tissue in Mytilus) is still significant $(\mathrm{p} \leq 0.0001)$. Because of the difference observed between the intoxication levels of the two types of shellfish, only data from M. edulis are used in the rest of the paper, unless otherwise stated.

\section{Geographic distribution of PSP toxicity and abundance of $A$. tamarense}

In spite of the high spatial and temporal variability of the data, clear geographic patterns in the distribution of the maximum values of the shellfish PSP toxin level and in A. tamarense abundance emerged. Throughout the years 1984-1994, maximum concentrations of PSP toxicity occurred only in the region of the Lower Estuary and the northern coast of the Gaspé Peninsula (Fig. 4A). Detectable levels of toxin were observed along the north shore of the Gulf of St. Lawrence (Natashquan to Baie-desHomards) and the south coast of the Gaspé Peninsula, in the Baie des Chaleurs. Toxicity was not observed along the northeastern coast of the Gulf of St. Lawrence (Tête-à-la-Baleine to Natashquan), nor in the lagoon of the Magdalen Islands. Although fewer data are available, the spatial distribution of the A. tamarense maxima had a similar pattern (Fig. 4B). The highest values were observed in the Lower
Estuary and along the northeastern Gaspé coast. It is interesting to note that even in the "toxin free" areas like the Magdalen Islands, A. tamarense cells were observed almost every year, although in very low numbers (100 cells or less per liter).

The same geographic pattern emerges if, instead of plotting the maxima PSP toxicity, the average length of time at which PSP toxicity levels remained above the regulatory limit is plotted (Fig. 4C). The north and south shores of the Lower Estuary and the northeastern coast of the Gaspé Peninsula experience the longest closure periods. On both sides of these high-risk areas, there is a region of the coast where the periods of closure due to toxicity are progressively shorter and are often not observed every year.

In order to detect patterns within the high-risk area (locations where PSP toxicity was $1000 \mu \mathrm{g}$ STX eq/100 gr tissue, or higher, and average length of closure period was above 30 days), correlation analysis between logarithms of the toxicity data of all sampling stations (Lower Estuary and northern coast of the Gaspé peninsula) was done (Table 1). The results show, first, a significant correlation between all sites and, second, the existence of groups of stations that are more highly correlated. These higher correlations (oblique lined boxes, in Table 1) allow us to define sub-regions within the area. At one end of the "Lower Estuary group," one such sub-region is defined by the stations of Tadoussac and Escoumins on the north shore and Baie-desHa!-Ha! on the south shore. At the other end of the

TABLE 1. - Results of the correlation analysis between the logarithm of the PSP mussel toxicity data from 1984 to 1994 for all the stations

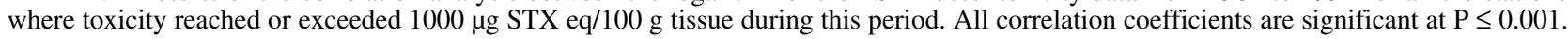

\begin{tabular}{|c|c|c|c|c|c|c|c|c|c|c|c|c|}
\hline & $\begin{array}{l}\text { Baie } \\
\text { Homards }\end{array}$ & $\begin{array}{l}\text { Point } \\
\text { Monts }\end{array}$ & Escoumins & Tadoussac & $\begin{array}{l}\text { Baie } \\
\text { Ha!-Ha! }\end{array}$ & Ste-Luce & Cap-Chat & Mont-Louis & $\begin{array}{l}\text { Petite } \\
\text { Vallée }\end{array}$ & $\begin{array}{l}\text { Cap } \\
\text { Rosiers }\end{array}$ & $\begin{array}{c}\text { Point } \\
\text { St. Pierre }\end{array}$ & Percé \\
\hline Baie Homards & 1 & & & & & & & & & & & \\
\hline Point des Monts & 0.34 & 1 & & & & & & & & & & \\
\hline Les Escoumins & 0.42 & 0.43 & 1 & & & & & & & & & \\
\hline Tadoussac & 0.47 & 0.39 & $\mathbb{2} 83$ & 1 & & & & & & & & \\
\hline Baie des Ha!-Ha! & 0.37 & 0.53 & $\mathbb{Q} \mathbb{O} \mathbb{Q}$ & $\mathbb{0} 0$ & 1 & - & & & & & & \\
\hline Ste-Luce & 0.35 & 6067 & 2063 & 0.52 & 702 & 1 & & & & & & \\
\hline Cap-Chat & & $\angle 0,67$ & 0.53 & 0.53 & $\angle 06$ & $\mathbb{0} \mathbb{0}$ & 1 & & & & & \\
\hline Mont-Louis & & $\angle 061$ & 0.36 & 0.34 & & 0.44 & \&.63 & 1 & & & & \\
\hline Petite Vallée & & 0.56 & 0.43 & 0.37 & & $\mathbb{1} / 3$ & $\mathbb{O}$ & \% & 1 & & & \\
\hline Cap-des-Rosiers & 0.32 & 0.53 & 0.42 & 0.45 & 266 & & 066 & 6063 & 0,3 & 1 & & \\
\hline Point St. Pierre & 0.48 & 0.38 & 0.31 & 0.36 & & 6063 & 0.42 & 0.52 & 0.56 & $\mathbb{Q} \%$ & 1 & \\
\hline Percé & 0.47 & 0.22 & 0.2 & 0.26 & & 0.59 & 0.31 & 0.39 & 0.43 & 0.61 & ra & 1 \\
\hline Newport & 0.45 & 0.34 & 0.38 & 0.33 & & 0.61 & 0.27 & & 0.41 & 066 & \&81 & 60 \\
\hline
\end{tabular}




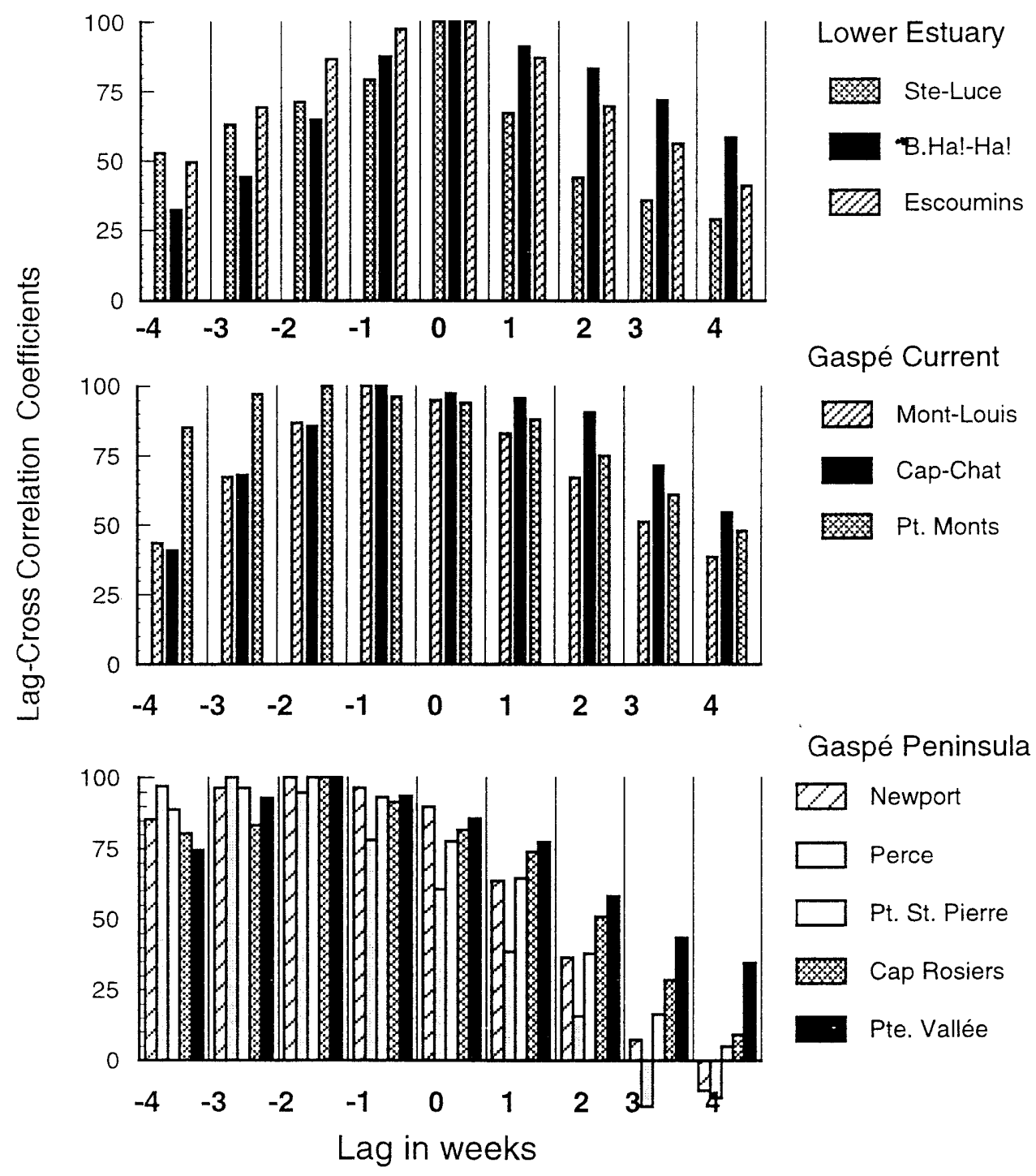

FIG. 5. - Results of the lag cross correlation analysis between the PSP data from Tadoussac, the most upstream station, versus each of the sampling sites downstream. The results are expressed in percentage of the maximum correlation and show a shift in the timing of the toxicity outbreaks, as well as clear grouping of the stations. The increasing negative lag between Tadoussac and the downstream stations suggests that the bloom starts downstream in the near-Gulf stations and works its way upstream to Tadoussac.

estuary, the "Gaspé Peninsula group," is defined by the stations of Point-Saint-Pierre, Percé, and NewPort. Not as well defined, but still noticeable, is a third group formed by Point des Monts on the north shore and Ste-Luce, Cap-Chat and Mont-Louis on the south shore. This group we will call the "Gaspé Current group." One can also observe in the same figure a clear pattern of high correlation coefficients between geographical neighboring sites, all along the coast of the Gaspé Peninsula and further upstream. It is worth noting that, although its correlations with several sites are still significant, the Baie-des-Homards site does not seem to align with any specific group of stations.
To further analyse the geographical pattern, lag cross correlations were calculated between the toxicity data of Tadoussac, the most upstream site, and the toxicity data of each site downstream. Baie-des-Homards did not seem to be closely related to the rest of the stations, so it was excluded from this analysis. The results, expressed in percentage of the maximum correlation (Fig. 5), show that there is a gradual shift in the timing of the toxicity outbreaks, from the open Gulf towards the upstream end of the Estuary. The timing of the outbreaks identifies the same groups of sites as defined previously: Tadoussac, Les Escoumins on the north shore and Baie-des-Ha!-Ha! and Ste- 

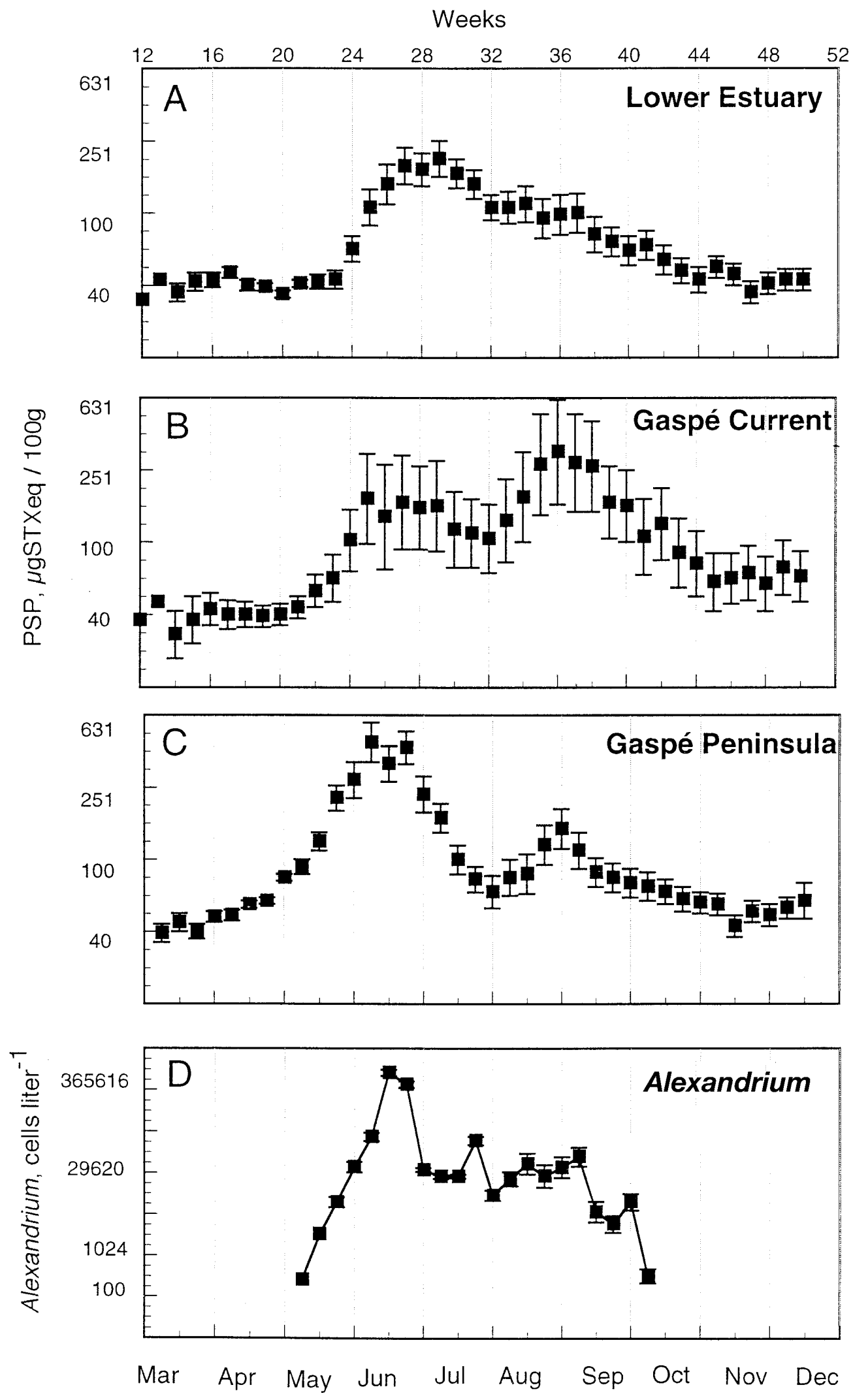

FIG. 6. - Geometrical mean weekly patterns of the PSP shellfish toxicity for the ten-year period 1984 to 1994 are shown in panels A, B and C. Included are data from all samples. The stations have been grouped according to the previously defined subregions. D: Monthly variation of A. tamarense cell concentrations averaged over the six year-period 1989 to 1994. Included are data from all samples from the stations: Tadoussac, Baie-Comeau, Ste-Flavie and Mont-Louis. 
Luce on the south shore remain together. Their toxicity outbreaks occur two to three weeks later than the outbreaks of the stations at the eastern tip of the Gaspé Peninsula, and one to two weeks later than the outbreaks at Point-des-Monts, Cap-Chat, and Mont-Louis.

\section{Seasonal variability of PSP shellfish toxicity and A. tamarense concentration}

Toxicity data and A. tamarense observations from the St. Lawrence region have distinct annual distributions, in which the evolution of the maximum differs according to the previously defined geographical groups or subregions (Fig. 6A, B, C).
Early in the spring (March and April), PSP toxicity values are barely detectable over the entire area. Early in May both the toxicity values and the $A$. tamarense cell numbers are low. With the progression of the season (May-June) both the toxicity and cell numbers start to increase. On the Eastern Shore of the Gaspé Peninsula (Fig. 6C), this phenomenon usually occurs from mid to late May. In the Lower Estuary and along the northern coast of the Gaspé Peninsula (Gaspé Current region), the rise in toxicity and cell numbers begins later, during the month of June (Fig. 6A and B). The rate of increase is rapid, and by the middle of June, the harvesting of shellfish is prohibited at most sites, and concentrations exceeding 1000 cells per litre
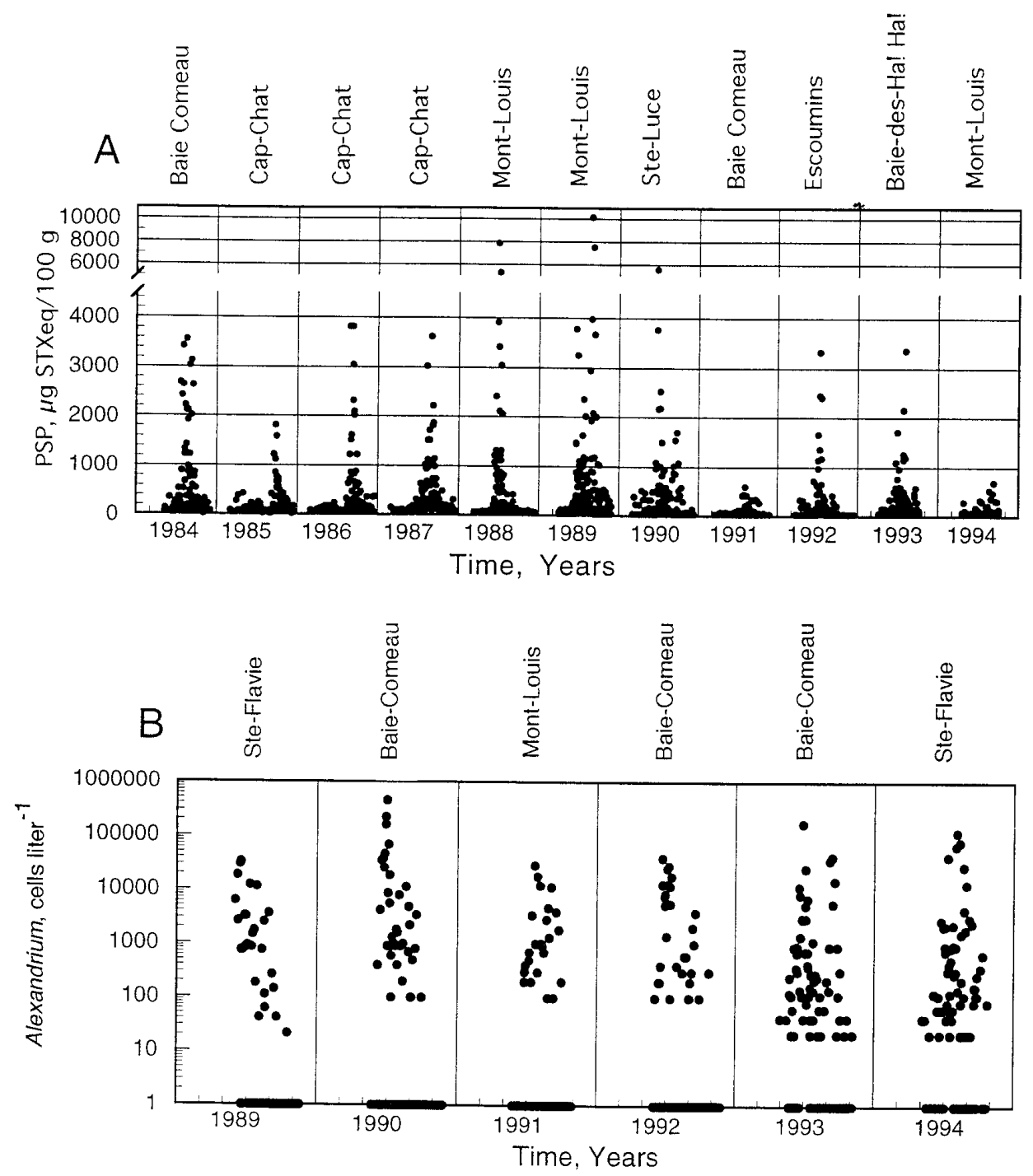

FIG. 7. - A, PSP toxicity measurements for M. edulis from 1984 to 1994 at the locations of Tadoussac, Les Escoumins, Baie-Comeau, Baiedes -Ha!-Ha!, Ste-Luce, Cap-Chat and Mont-Louis. Each dot represents a measurement made during that year. The name above each year indicates the station where the maximum toxicity was observed that year. B, A. tamarense cell concentrations from 1989 to 1994 at the monitoring stations of Baie-Comeau, Tadoussac, Ste-Flavie, and Mont-Louis. The dots represents individual measurements made during that year. Above each year, the station where the maximum cell concentration was observed is indicated. 
of A. tamarense are observed in most of the water samples (Fig. 6D). Maximum values of both PSP and cell numbers are reached in the mid-June or early July depending on the area.

In the upstream region of the Estuary along both the north and south shore (Fig. 6A), there is slow decrease through the rest of the summer, after the initial peak. Base-line levels of toxicity and Alexandrium are found again at the end of October. In the Gaspé Current (Fig. 6B), after a brief period with high values, PSP levels and A. tamarense concentrations decrease (July). In August-September another increase occurs in both the PSP shellfish toxicity and A. tamarense abundance. In this second bloom, the values are often higher than during the first one (Fig. 6B). After this second peak $A$. tamarense concentrations decline again rapidly, and PSP toxicity declines immediately after. If this second peak is of high intensity, the PSP toxicity remains detectable until the end of the monitoring period, and sometimes stays at this level up to early spring (March) of the following year. At the eastern end of the Gaspé peninsula the development is quite different (Fig. 6C): the rise and fall in toxicity is extremely sharp. Then, PSP and Alexandrium decline sharply towards the end of July. Later, at the end of August, PSP rises again.

The mean Alexandrium seasonal distribution (Fig. 6D) is similar to the seasonal toxicity pattern, however, because the sampling is not as extensive in years, sites, and season, distinct patterns for each individual group could not be calculated.
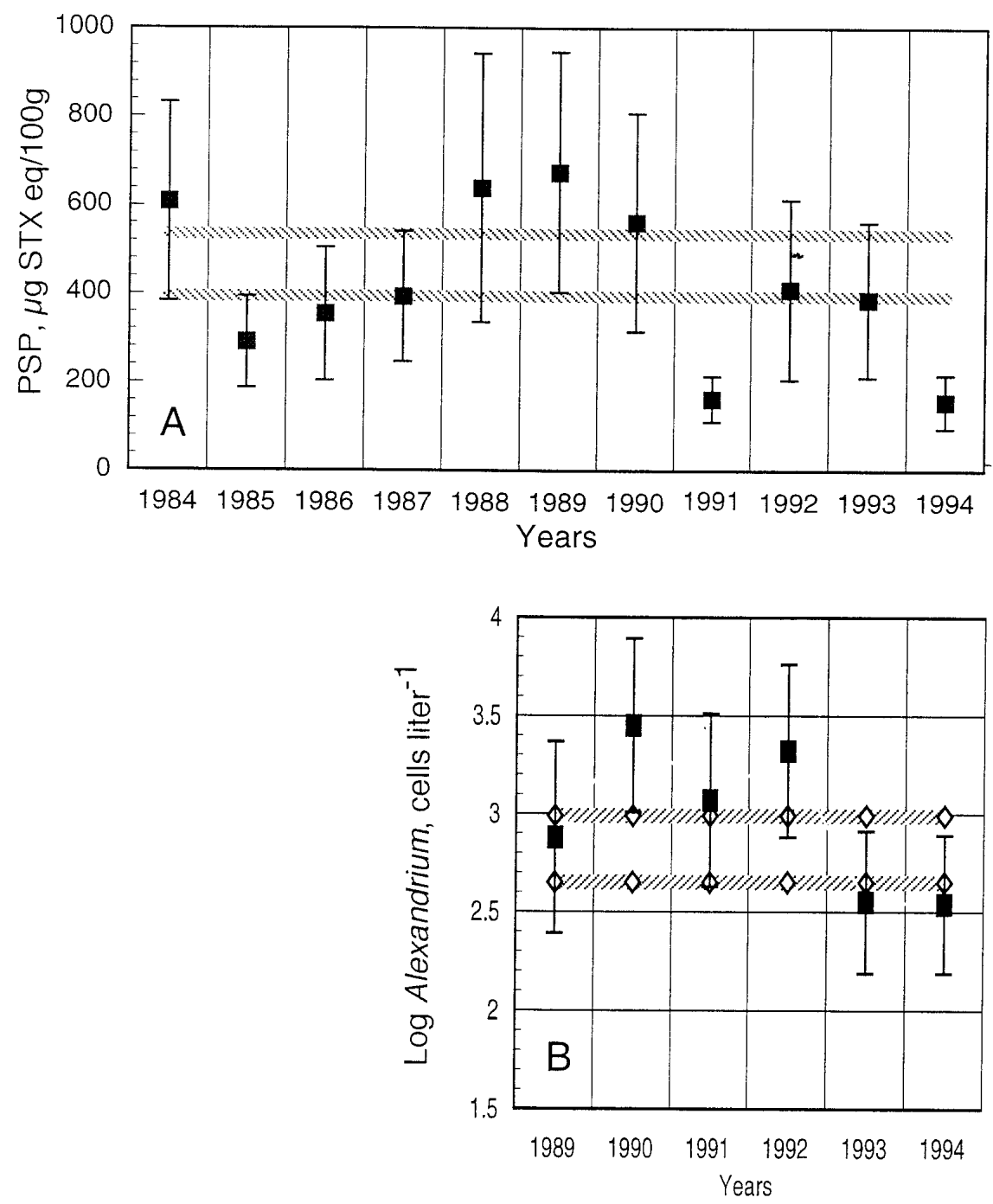

FIG. 8. - A, Annual means and $99 \%$ confidence limits based on all samples which exceeded 50 $\mu \mathrm{g}$ STX eq/100g tissue from the stations situated in the Lower St. Lawrence Estuary and along the northern coast of the Gaspé peninsula. The horizontal bars (striped) indicate the 99\% confidence limits of the overall mean for the ten-year period 1984 to 1994. B, Annual means and $99 \%$ confidence limits of the logarithm of A. tamarense cell concentrations for the stations of Tadoussac, Baie-Comeau, Ste-Flavie and Mont-Louis. Striped bars have the same meaning as in Fig. 8A. 

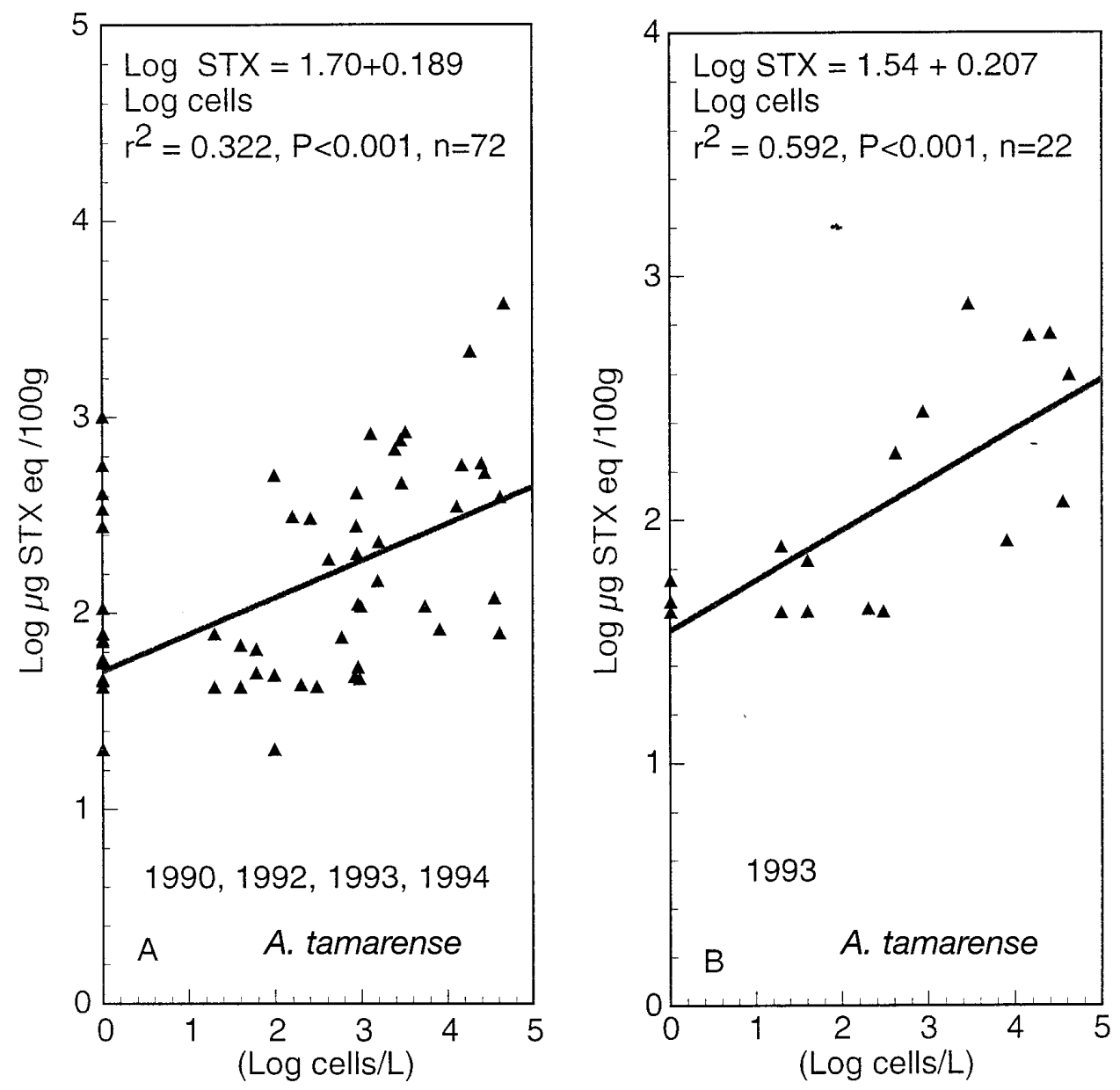

FIG. 9. - Regression analysis of the logarithm data: PSP toxicity of M. edulis and A. tamarense cells from the Mont-Louis Station. A: All data for years 1990, 1992, 1993 and 1994. B: Only the data collected during 1993.

\section{Interannual variability of PSP and $A$. tamarense concentrations}

Figure 7 shows all the values of PSP in Mytilus recorded between 1984 and 1994 for all stations along the coast of the Lower Estuary. It indicates the scale of variation in the maximum toxin concentration. Note that the maximum occurs at different sites each year. Statistical analysis of these data (Fig. 8A) confirms this high variability and shows that in 1989 PSP in the region was significantly higher (F test $\mathrm{p} \leq 0.005$ ) than the mean for all data, while in 1991 it was significantly lower. No decreasing or increasing trend during the eleven years of data is observed.

The logarithmic plot of the cell concentration of Alexandrium recorded in the same area between 1989 and 1994 (Fig. 7B) shows less inter-annual variability than the PSP. Only in 1990 (Fig. 8B) were cell densities significantly higher. As is observed in the geographical distribution of the PSP maxima, the peaks in cell numbers are at different locations each year.

\section{Relationship between $A$. tamarense cell concen- tration and PSP in M. edulis}

At the Mont-Louis station, samples for the determination of $A$. tamarense abundance and PSP in mussels were collected on the same day and location. This allowed a closer look at the interrelationship between the two variables. Regression analysis of all the logarithmically smoothed data shows significant correlation $(p \leq 0.0001)$ between the two variables (Fig. 9A). Analysis of 1993 (Fig. 9B) showed that $59 \%$ of the variability in PSP is explained by the Alexandrium cell concentration. A closer look at this year (Fig. 10) clearly shows the similarity in the temporal pattern distribution, even though a difference between the absolute values of toxicity and Alexandrium is evident. The timing of 


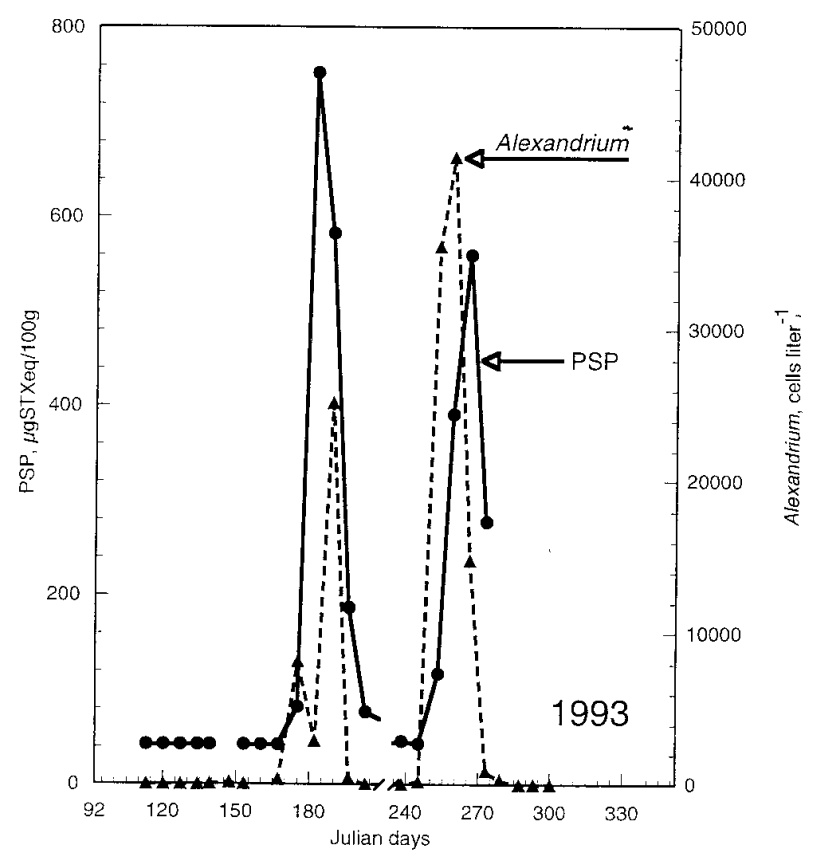

FIG. 10. - Comparison of toxicity levels of M. edulis with the A. tamarense cell concentration during the sampling season of 1993 at the Mont-Louis sampling station. the toxin rise in the mussels coincides with the increase in A. tamarense concentration, and detoxification starts when $A$. tamarense decreases below observation levels.

The coincidence between the rise of the PSP toxin and the appearance of $A$. tamarense in the water column is still evident even when the samples for the shellfish toxicity and Alexandrium cell concentrations were collected several $\mathrm{km}$ apart. This can be seen in Fig. 11, where mussels and water samples from the Ste-Luce/Ste-Flavie area (8 to 12 $\mathrm{km})$ are compared.

Linear regression analysis between the first date in the season when A. tamarense reaches 1000 cells per litre, and the first date on which mussel toxin levels reach the $80 \mu \mathrm{g}$ SXT eq/100g tissue regulatory level, has an $r^{2}$ of 0.785 (Fig. 12). In this analysis all pairs of data available during the six years of monitoring have been used. Except the data from Mont-Louis (three points), toxicity and Alexandrium data are from adjacent geographical sites, but separated approximately by 10 to $15 \mathrm{~km}$. The highly sig-
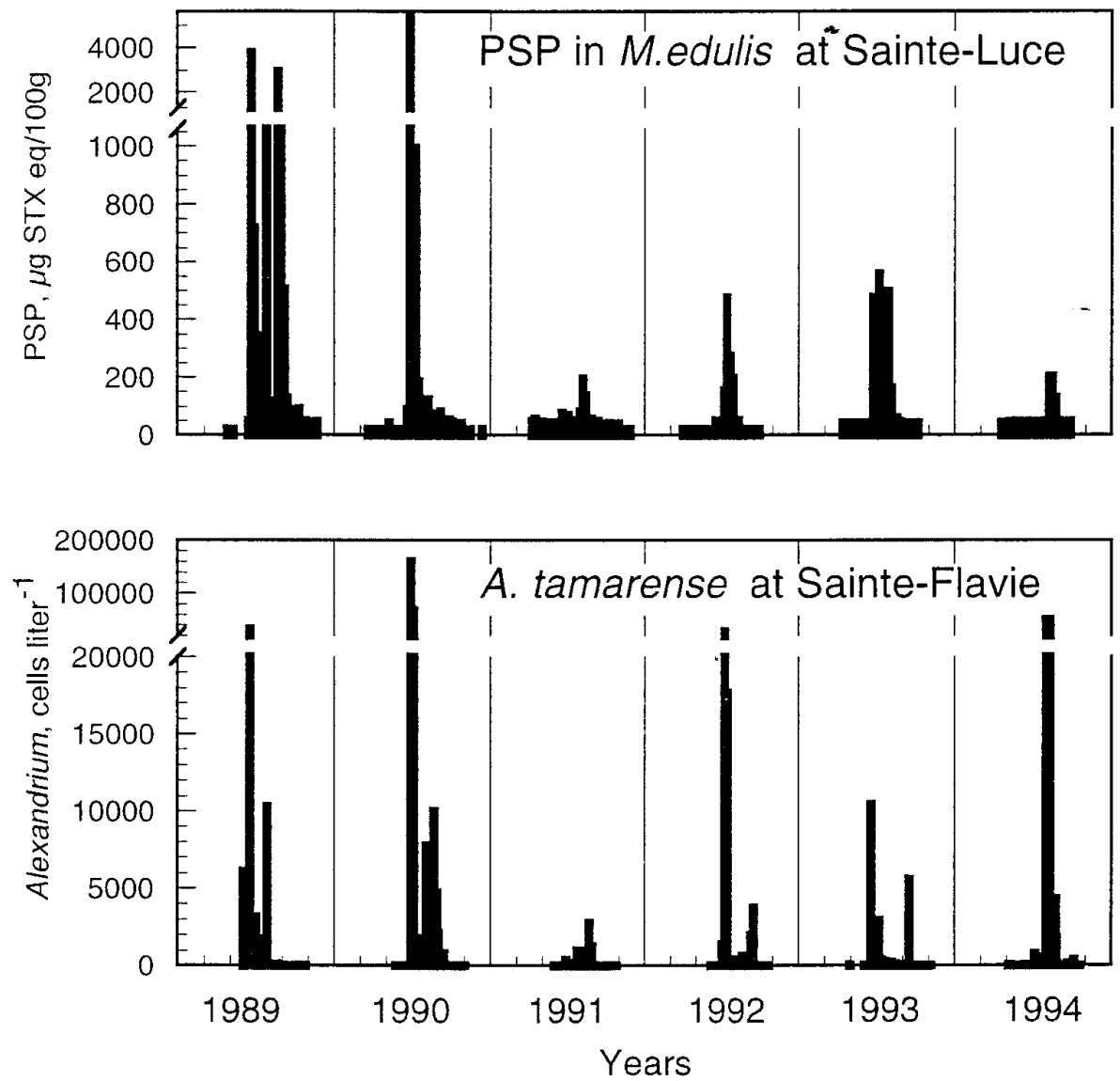

FIG. 11. - Comparison of PSP toxicity levels of M. edulis at the Ste-Luce station with the A. tamarense cell concentration at the Ste-Flavie station for the period 1989 to 1994 . Both are stations in the estuary, but the Ste-Luce site is $11 \mathrm{~km}$ upstream from the Ste-Flavie site. 


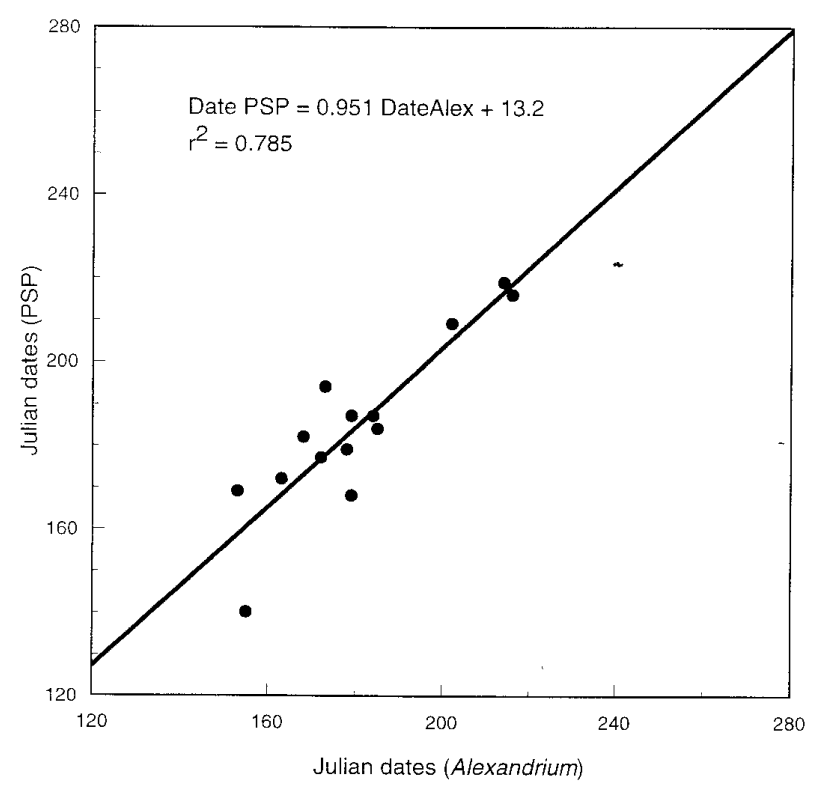

FIG. 12. - Relationship between the first date (Julian days) in the season when PSP toxicity in M. edulis reached the mandatory closing limit of $80 \mu \mathrm{g} \mathrm{STX} \mathrm{eq} / 100 \mathrm{~g}$ tissue and first date when $A$. tamarense cells in the water column equaled or exceeded 1000 cells/L. All pairs of data for the six-year period 1989 to 1994 have been used. The highly significant slope $(\mathrm{P}<0.0001)$ is not statistical different from one-to-one.

nificant slope $(p \leq 0.0001)$ is not statistically different from one, indicating an immediate contamination of the shellfish as soon as Alexandrium is present in the water.

\section{DISCUSSION}

\section{Accumulation of toxins in Mytilus edulis versus Mya arenaria}

It has been often reported throughout the literature that at a given locality toxicity levels in mussels are higher than in soft-shell clams (Prakash et al., 1971; Hurst and Yentsch, 1981; Yentsch and Inze, 1981; Martin and Richard, 1996). In fact, in some monitoring programmes mussels are used as sentinel species, though quantitative justification of this choice is very scarce. The only existing field data for this region is by Gilfillan et al. (1976), who found that during an outbreak of PSP on the Maine coast, $M$. edulis became six times more toxic than $M$. arenaria. The results presented in this paper (Fig. 2A), based on eleven years of observations just $5^{\circ}$ latitude north of the Gulf of Maine, confirm this observation. Previous laboratory experiments have shown that at Alexandrium concentrations $\geq 10^{6}$ cells $/, M$. arenaria was more resilient to becoming toxic than $M$. edulis (Cucci et al., 1985; Shumway and Cucci, 1987). Our data does not permit speculation on the cause of observed differences, but certainly shows that the phenomena occurs even at much lower Alexandrium cell densities than those used in the laboratory. The regression line obtained with the present data (Fig. 3A and B) supports the use of $M$. edulis as a sentinel species for shellfish toxicity outbreaks in the St. Lawrence region. However, it argues caution in defining broad harvesting regulations which include different shellfish species, and warns about mixing PSP data from different species in analysis of long term trends, geographical distributions, etc. of shellfish toxicity or of toxic dinoflagellates blooms.

\section{Geographical and temporal patterns of PSP tox- icity and $A$. tamarense}

The general spatial and temporal patterns described here (Fig. 4) corroborate the previous distribution of PSP and A. tamarense in this region (Prakash et al., 1971; Beaulieu and Ménard, 1985; Therriault et al., 1985; Cembella and Therriault, 1989; Larocque and Cembella, 1991). As observed in other regions (Hurst and Yentsch, 1981; White, 1987; Martin and White, 1988; Franks and Anderson, 1992a), the large-scale geographical pattern of PSP toxicity and A.tamarense seems to follow the typical summer hydographical features of the St. Lawrence region (El-Sabh, 1979; Koutikonsky and Budgen, 1991). At first sight (Fig. 4 and Fig. 1), an association between the high PSP risk area and/or high A. tamarense concentrations and the omnipresent Gaspé Current is quite evident. This relationship with the Gaspé Current was noted in previous studies (Therriault et al., 1985; Larocque and Cembella, 1991). However, closer inspection leads to an exploration of the role that the hydrodynamics of the Gulf of St. Lawrence and Lower Estuary system (Fig. 13) might play.

In the Lower Estuary, the precursor of the Gaspé Current begins to form along the south shore and is reinforced by a current crossing the estuary from the north shore. The two coastal anchor points of this transverse current are Point des Monts in the north and Cap-Chat in the south. This transverse current marks the separation between the upstream and downstream quasi-permanent eddies: the Rimouski Eddy and the Anticosti Gyre (Gratton et al., 1988; El-Sabh, 1979). The results of the cross correlation analysis presented in this paper (Table 1) are easily 


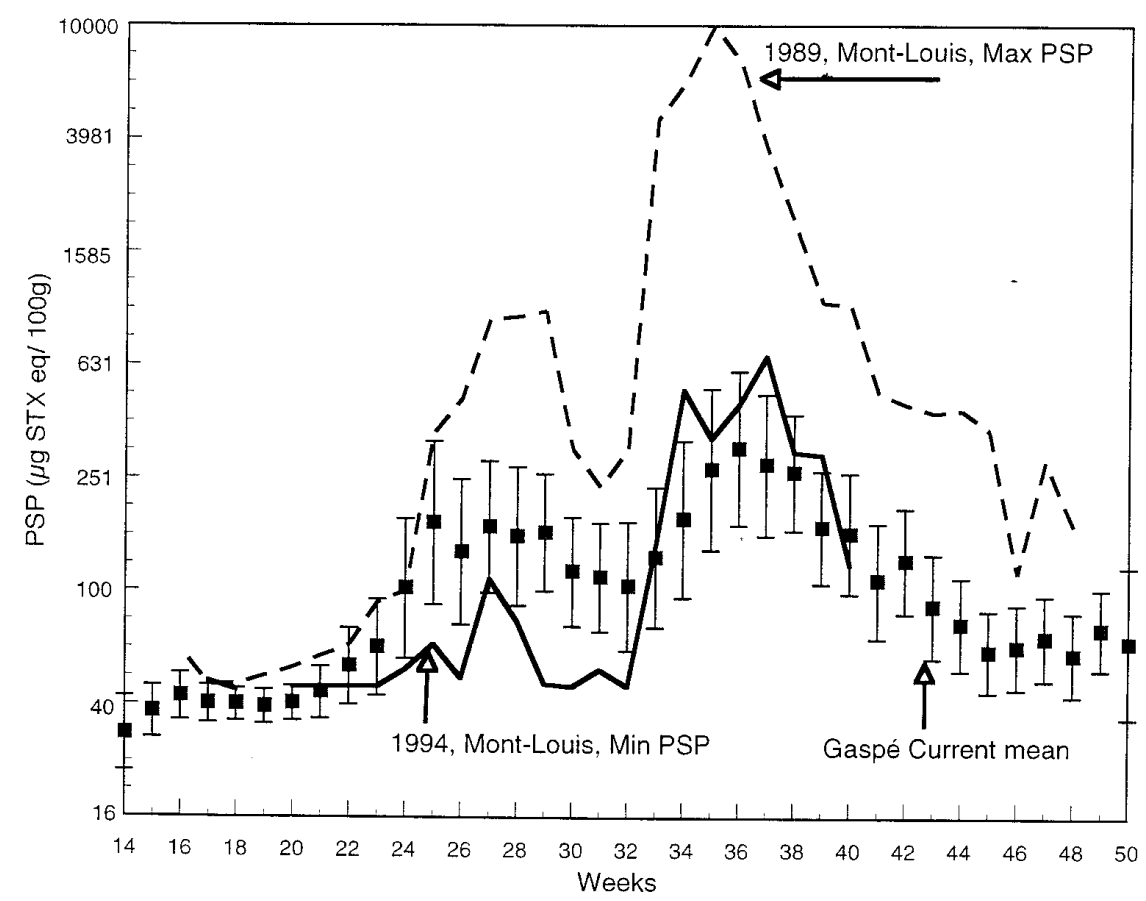

FIG. 13. - Seasonal distribution of the geometrical mean of PSP toxicity for the ten-year period 1984 to 1994 for all data collected at the Gaspé current stations (square symbols and 99\% confidence limits). The Gaspé Current stations are identified in Figs. 5 and 6B. Continuous line (-) represents the PSP toxicity values at the Mont-Louis site during 1994, the year of minimum PSP values. The broken line (- - -) represents the PSP toxicity values at the Mont-Louis site during 1989, the year of maximum PSP values. The general wave shape of all three curves is the same.

explained on the basis of the above mesoscale hydrographic setting. The subgroup of stations Tadoussac, Les Escoumins, Baie des Ha!-Ha! and Ste-Luce are all located around the Rimouski Eddy. The observed higher correlation between Point-desMonts and Cap-Chat rather than between Point-desMonts and Les Escoumins can be attributed to the existence of north-south transverse current. The relatively "independent " station of Baie-des-Homards is located in a completely different hydrographic subsystem from the others.

Superimposed on this general mesoscale trend are large fluctuations in the currents, tides, freshwater runoff, and local winds (Gratton et al., 1988; Mertz et al., 1988; Vezina et al., 1995). This instability in the hydrographic regime explains much of the considerable interannual variability observed in the PSP toxins and A. tamarense concentrations (Fig. 7 and 8). Larocque and Cembella (1990) argue that this hydrographic instability is responsible for the localization and the magnitude of the outbreaks along both shores of the Lower Estuary.

In contrast, further downstream, the Gaspé Current is a well developed coastal jet 15 to $20 \mathrm{~km}$ wide at the top of the $40-50 \mathrm{~m}$ water column with surface velocities as high as $1 \mathrm{~m} \mathrm{~s}^{-1}$ (El-Sabh and
Benoit 1984). Frictional induced upwelling occurs along the northern edge and downwelling occurs along the southern edge (Tang, 1980; Levasseur et al., 1990). Constant nutrient input due to the upwelling combine with vertical stratification due to the freshwater runoff and the solar heating to generate favourable conditions for development of autotrophic dinoflagellate populations (Pingree et al., 1976; Margalef, 1978; Holligan, 1979; Margalef et al., 1979). Strong coastal current and downwelling have been demonstrated as important mechanisms for surface accumulation of toxic algal-blooms and transport along the coast (Franks and Anderson, 1992a). The northern Gaspé coast seems to comply with all these requirements, so it is not surprising that this region is where PSP has the least interannual variability and the most temporal persistency (Fig 4). Furthermore, the dominant presence of the Gaspé Current can also explain the high correlation observed between the stations situated along this shore.

Strong coastal surface currents have often been proposed as major players in the transport of blooms of $A$. tamarense and consequently a potential mechanism for downstream intoxication of shellfish along a coast (Franks and Anderson 
1992b). In the St. Lawrence region it has also been hypothesised that the A. tamarense cysts and blooms of the Lower Estuary might be the source of the toxicity of the shellfish along the coast of the Gaspé peninsula (Therriault et al., 1985; Cembella et al., 1988a; Trites and Drinkwater, 1991). One of the most striking findings of this study was that in spite of the presence of the strong Gaspé Current, a downstream progression of the timing of the toxic shellfish outbreaks from the head of the Lower Estuary towards the tip of the Gaspé Peninsula was not observed. On the contrary, the onset of the mussel toxicity clearly progresses upstream from the Gulf region into the Estuary.

The seasonal development of the spring phytoplankton bloom is not synchronous over the entire St. Lawrence region (Sevigny et al., 1979; Lafontaine et al., 1991). The onset of the bloom clearly spreads upstream from the northwestern part of the Gulf towards the Lower Estuary, in April-May in the Gulf and from June to beginning of July in the Lower Estuary (Levasseur et al., 1984). The results presented above suggest that $A$. tamarense blooms follow the same trend. Our proposed hypothesis is that the onset and subsequent increase of $A$. tamarense coincide with the traditional progression of the phytoplankton succession diatoms-dinoflagellates-small flagellates as nutrient depletion and water column stratification proceeds with the season. This will explain the overall significant correlation observed between all the sites in the St. Lawrence region as well as the upstream gradient observed in the timing of the PSP appearance. The clear matching pattern of the seasonal relationship between the PSP and Alexandrium in the St. Lawrence and its parallel in the Fundy-Gulf of Maine region (Hurst and Yentsch, 1981; Martin and White, 1988; Martin and Richard, 1996), supports the hypothesis that the timing of the development of the Alexandrium blooms in the two regions is controlled by the same environmental factors.

On the other hand, for the absolute magnitude as well as the duration of the Alexandrium blooms at a given site, small-scale local hydrographic-features specific to each subregion and site appear to be the dominant drivers. This would explain the high interannual variability at the sites where the maxima occur as well as the clear subregional differentiation observed in the data. The hypothesis that the onset/development of the blooms and the absolute magnitude of these blooms are controlled by different mechanisms is further confirmed by the similar- ity in the seasonal pattern observed in high and low PSP years (Fig. 13). It is interesting to notice that the considerable geographical and interannual smallscale variability of the St. Lawrence region is a feature common also to the Bay of Fundy and the Gulf of Maine coast.

A corollary to the above hypothesis is that a better understanding of the Alexandrium outbreaks and its associated PSP throughout the St. Lawrence region, and probably in other neighboring regions as well, would be achieved if, in future studies, the different stages or levels of the bloom dynamics were separated. A first level study would be one in which Alexandrium was just any other organism of the autotrophic dinoflagellate community. The source of the initial inoculum, key factors that trigger their growth, mechanisms of accumulation of the cells, winter survival, etc. would be investigated in the context of the general processes that control the traditional scenario of phytoplankton seasonal succession. During this period, Alexandrium temporal and spatial distribution studies should not be disassociated from the studies of the other dinoflagellates. A second level study would be one in which Alexandrium outcompetes other dinoflagellates and produces massive blooms. In this situation unique species characteristics such as cyst dormancy period, regulation of cyst germination, species dispersal, cyst-bed distribution, life history strategy, toxin concentration and species-specific environmental requirements might be critical. With few exceptions (Incze and Yentsch, 1981), during the last decade (Joint et al., 1997; Anderson, 1997) most research effort has focused on acquiring new information at this second level. Nevertheless, it is clear that some important questions remain unanswered. We suggest that an increase in basic knowledge of the development and growth of the entire dinoflagellate community and even of the phytoplankton species succession will facilitate the identification of mechanisms governing bloom dynamics. This will provide many broader and probably different perspectives on relevant topics such as why PSP free areas are imbedded in/or adjacent to PSP recurrent areas, possible consequences of the interaction between hydrographic and weather patterns on the formation and persistence of blooms, or the extent to which an increase in eutrophication affects red-tide organisms. In short, an increase in basic knowledge of the development and growth of the entire dinoflagellate community will furnish new insight on how to solve, or how to approach these questions. 


\section{PSP shellfish toxicity and Alexandrium tamarense}

An association of PSP with A. tamarense has long been recognised (Medcof, 1947; Prakash, 1967). It has also been hypothesised that the resting stage of Alexandrium, the benthic cyst itself, may be the source of observed shellfish toxicity (Dale et al., 1978). In the maritime St. Lawrence estuary, large concentrations of cysts have been observed in some regions (Cembella et al., 1988a; Turgeon et al., 1990; Castell et al., 1998). However, our observations of the good correspondence between the spatial and temporal distribution of PSP and Alexandri$u m$ in the water column seems to indicate that the motile stage of Alexandrium is mostly responsible for the shellfish toxicity. The strong evidence is provided by the significant positive correlation between these two variables (Fig. 9), as well as their distinct seasonal pattern (Fig. 6).

Total PSP accumulation in the shellfish depends on the cell density of Alexandrium and the toxin concentration of the individual cells (Chebib et al., 1993). However, it is also largely dependent upon filtration rates, behaviour and response of the shellfish in the presence of toxic algae, intoxication and detoxification rates of the shellfish, plus differences in the metabolism and catabolism of the individual toxins by the shellfish (Dupuy and Sparks, 1968; Gillfillan and Hansen, 1975; Cucci et al.,1985; Twarog et al., 1972; Twarog, 1974; Shumway and Cucci, 1987; Desbiens et al., 1990). Considering all the above processes, the indirect correlation between the absolute maximum concentration of PSP mussel toxin and Alexandrium cells, as well as the observed differences in the timing of those peaks (Fig. 10), is not surprising. Given all this, it is more difficult to reconcile the results of the regression analysis between the first date in the season on which $A$. tamarense reaches 1000 cells per litre and the first date on which the mussel's toxin level reaches the 80 $\mu \mathrm{g}$ SXT eq/100g tissue regulatory level (Fig. 12). However, initially the accumulation of toxins in the mussels is just a function of toxin concentration in the water and filtration rates (Silvert and Cembella, 1995). The slope of 1 (Fig. 12) agrees with previous observations (Yentsch and Inze, 1981; Gilfillan and Hansen, 1975; Chebib et al., 1993) that mussel contamination occurs within hours, but indicates that the weekly monitoring frequency normally used is insufficient and needs to be increased. However the most important finding of this study is that concentrations of Alexandrium as low as 1000 cells per litre, are enough to raise the toxin levels in the mussels to $80 \mu \mathrm{g}$ SXT eq/100g tissue and force the suspension of the shellfish harvesting activities.

Alexandrium blooms have long been considered the major cause of PSP shellfish toxicity along most of the world's coasts. Because of this, considerable efforts are being made to study this organism and to define the relationship between these two phenomena (Reynolds and Smayda, 1998). Most recently, many major research programmes such as ECOHAB have selected this topic as a major objective. Traditionally, it has been considered that major blooms, i.e. red tides, were necessary to impact the shellfish industry (Bricelj and Shumway, 1998), so most efforts have concentrated on studying the periods or areas in which they occur (Hallegraeff, 1993). Here we show that cell concentrations far below red tide concentrations set up PSP levels high enough to close shellfish harvesting activity. New investigations employing improved time-space sampling frequency and cell enumeration are needed to qualify and quantify the exact mechanism behind the Alexandrium-PSP relationship during periods when Alexandrium concentrations are low.

\section{ACKNOWLEDGEMENTS}

We thank A. Cembella for his valuable assistance; M. Desbiens, B. Hupertz, R. Larocque, S. Michaud and B. Mirand for collecting and processing some samples; and C. Savenkoff for constructive comments and valuable help with the data analysis. Fisheries and Ocean Canada, the Institut de Ciències del Mar, CICYT project MAR98-0932, and BIOHAB project EVK3-1999-00072 provided financial support. This is a contribution of the Toxic Algae Program of the Maurice Lamontangne Institute (Québec) and the Institut de Ciències del Mar, CSIC (Barcelona).

\section{REFERENCES}

Association of Official Agricultural Chemists (AOAC). - 1975. Biological Method, 12, Official Methods of Analysis of the $A O A C$, pp. 319-321, AOAC, Washington D.C.

Anderson, D.M., D.M. Kulis, J.A. Orphanos and A.R. Ceurvels. 1982. Distribution of the toxic dinoflagellate Gonyaulax tamarensis in the Southern New England Region. Estuar. Coast. Shelf. Sci., 14: 447-458.

Anderson, D.M. - 1997. Diversity of harmful algal blooms in coastal waters. Limnol. Oceanogr., 42: 1009-1022.

Beaulieu, J.L. and J. Menard. - 1985. Study of the Québec shellfish toxicity data (1955-1983). 445-450. In: D.M. Anderson and D.G. Baden (eds.), Toxic dinoflagellates. pp. 445-450. Elsevier, New York. 
Blasco, D., M. Levasseur, R. Gelinas, R. Larocque, E. Bonneau, A.D. Cembella and B. Hupertz. - 1998. Monitorage du phytoplankton toxique et des toxines de type IPM dans les mollusques du Saint-Laurent: 1989-1994. Fisheries and Oceans Report No. 151.

Bricelj, V.M. and S.E. Shumway. - 1998. An Overview of the Occurrence and Transfer Kinetic of Paralytic Shellfish Toxins in Bivalve Molluscs. In: B. Reguera, J. Blanco, M. L. Fernandez and T. Wyatt (eds.), Harmful Algae. pp. 431-436. Intergovernmental Oceanographic Commission of UNESCO, Xunta de Galicia, Vigo.

Castell-Perez, C., S. Roy, M. Levasseur and D.M. Anderson. 1998. Control of Germination of Alexandrium Tamarense (Dinophyceae) cysts from the lower St. Lawrence estuary (Canada). J. Phycol., 34: 242-249.

Cembella, A.D., J. Turgeon, J.C. Therriault and P. Beland. - 1988a. Spatial Distribution of Protogonyaulax tamarensis Resting Cysts in Nearshore Sediments along the North Coast of the Lower St. Lawrence Estuary. J. Shellfish Res., 7: 597-609.

Cembella, A.D., J.C. Therriault and P. Beland. - 1988b. Toxicity of cultured isolates and natural population of Protogonyaulax tamarensis from the St. Lawrence estuary. J. Shellfish Res., 7: 611-621.

Cembella, A.D. and J.C. Therriault. - 1989. Population dynamics and toxin composition of Protogonyaulax tamarensis from the St. Lawrence estuary. In: D.M.A.T. Okaichi and T. Nemoto (eds.), Red tides: Biology, environmental science, and toxicology. pp. 81. Elsevier, New York.

Cembella, A.D. and M. Desbiens. - 1994. Fate of paralytic shellfish toxins in the American lobster Homarus americanus. J. Shellfish Res., 13: 302.

Chebib, H., A.D. Cembella and P. Anderson. - 1993. Differential paralytic shellfish toxin accumulation and detoxification kinetics in transplanted populations of Mytilus edulis exposed to natural blooms of Alexandrium excavatum. In: T.J. Smayda and Y. Shimizu (eds.), Toxic phytoplankton blooms in the sea, pp. 383388. Elsevier, Amsterdam.

Cucci, T.L., S.E. Shumway, R.C. Newell and C.M. Yentsch. 1985. A preliminary study of the effects of Gonyaulax tamarensis on feeding bivalve molluscs. In: D.M. Anderson, A.W. White and D.G. Baden (ed.), Toxic dinoflagellates. pp. 395400. Elsevier, Amsterdam.

Dale, B., C.M. Yentsch and J.W. Hurst. - 1978. Toxicity in resting cysts of the red-tide dinoflagellate Gonyaulax excavata from deeper water coastal sediments. Science, 201: 1223-1224.

Desbiens, M., F. Coulombe, J. Gaudreault, A.D. Cembella and R. Larocque. - 1990. PSP toxicity of wild and cultured blue mussels induced by Alexandrium excavatum in Gaspé Bay (Canada): implications for aquaculture. In: E. Graneli, B. Sundstrom, L. Edler and D.M. Anderson (eds.), Toxic marine phytoplankton. pp. 459-462. Elsevier, New York.

Desbiens, M. and A.D. Cembella. - 1995. Occurrence and elimination kinetics of PSP toxins in the American lobster (Homarus americanus). In: P. Lassus, G. Arzul, E. Erard, P. Gentien and C. Marcailloux (eds.), Harmful marine algal blooms. pp. 443438. Lavoisier Science Publishers, Paris.

Dupuy, J.L. and A.K. Sparks. - 1968. Gonyaulax washingtonensis, its relationship to Mytillus californianus and Crasostrea gigas as a source of paralytic shellfish toxin in Sequin Bay, Washington. Proceedings Nat. Shellfish Assoc., 58: 2.

El-Sabh, M.I. - 1979. The Lower St. Lawrence Estuary as a Physical Oceanographic System. Le Naturalist Canadien ,106: 55-73.

El-Sabh, M.I. and J. Benoit. - 1984. Variabilité spatio-temporelle du courant de Gaspé. Sc. Tech. Eau, 17: 55-64.

Franks, P.J.S. and D.M. Anderson. - 1992a. Toxic phytoplankton blooms in the southwestern Gulf of Maine: Testing hypotheses of physical control using historical data. Mar. Biol., 112: $165-174$.

Franks, P.J.S. and D.M. Anderson. - 1992b. Alongshore transport of a toxic phytoplankton bloom in a buoyancy current: Alexandrium tamarense in the Gulf of Maine. Mar. Biol. 112: 153-164.

Gilfillan, E.J. and S. Hansen. - 1975. Effects of paralytic shellfish poisoning toxin on the behavior and physiology of marine invertebrates. In: V.R.L. Cicero (ed.), Proceedings of the First International Conference on Toxic Dinoflagellate Blooms. pp. 367-375. Massachusetts Science and Technology Foundation,Wakefield, Massachusetts.
Gilfillan, E.S., J.W. Hurst, S.A. Hansen and C.P. Leroyer. - 1976. Final Report to the New England Regional Commission, Contract 10530699

Gosselin, S., L. Fortier and J.A. Gagné. - 1989. Vulnerability of marine fish larvae to the toxic dinoflagellate Protogonyaulax tamarensis. Mar. Ecol. Prog. Ser., 57: 1-10.

Gratton, Y., G. Mertz and J.A. Gagné. - 1988. Satellite observations of tidal upwelling and mixing in the St. Lawrence Estuary. $J$. Geophys. Res., 93: 6947-6954.

Hallgraeff, G.M. - 1993. A review of harmful algal blooms and their apparent global increase. Phycologia, 32: 79-99.

Holligan, P.M. - 1979. Dinoflagellate blooms associated with tidal fronts around the British Isles. In: D.L. Taylor and H.H. Seliger (eds.), Toxic Dinoflagellates Blooms. pp. 249-256. Elsevier, Amsterdam.

Hurst, J.W. and E.S. Gilfillan. - 1977. Paralytic shellfish poisoning in Maine. In: E. S. Wilt (ed.), Tenth National Shellfish Sanitation Workshop. pp. 152-161. U. S. Dept. Health, Education and Welfare, Food and Drug Administration, Washington, D.C.

Hurst, J.W. and C.M. Yentsch. - 1981. Patterns of Intoxication of Shellfish in the Gulf of Maine Coastal Waters. Can. J. Fish. Aquat. Sci. 38: 152-156.

Incze, L.S. and C.M. Yentsch. - 1981. Stable density fronts and dinoflagellate patches in a tidal Estuary. Estuar. Coast. Shelf Sci., 13: 547-556.

Joint, I., J. Lewis, J. Aiken, R. Proctor, G. Moore, W. Higman and M. Donald. - 1997. Interannual variability of PSP outbreaks on the northeast U.K. coast. J. Plankton Res., 19: 937-956.

Koutikonsky, V.G. and G.L. Budgen. - 1991. The Physical Oceanography of the Gulf of St. Lawrence: A review with emphasis on the synoptic variability of the motion. In: J.C. Therriault (ed.), The Gulf of St. Lawrence: small ocean or big estuary? Can. Spec. Publ. Fish. Aquat. Sci., 113: 57-90.

Lafontaine, Y.D., S. Demers and J. Runge. - 1991. Pelagic Food Web Interactions and Productivity in the Gulf of St. Lawrence: A Perspective. In: J.C. Therriault (ed.), The Gulf of St. Lawrence: small ocean or big estuary? Can. Spec. Publ. Fish. Aquat. Sci., 113: 99-123.

Larocque, R. and A.D. Cembella. - 1990. Ecological parameters associated with the seasonal occurrence of Alexandrium spp. and consequent shellfish toxicity in the lower St. Lawrence estuary (Eastern Canada). In: E. Graneli, B. Sundstrom, L. Edler and D.M. Anderson (eds.), Toxic marine phytoplankton. pp. 368-373. Elsevier, New York.

Larocque, R. and A.D. Cembella. - 1991. Résultats du premier programme de suivi des populations de phytoplancton toxiques dans l'estuaire et le golfe du Saint-Laurent (Region du Québec). Can. Tech. Rep. Fish. Aquat. Sci. 1792: 42.

Levasseur, M., J.C. Therriault and L. Legendre. - 1984. Hierarchical control of phytoplankton succession by physical factors. Mar. Ecol. Prog. Ser., 19: 211-222.

Levasseur, M., P.J. Harrison, B.R. Heimdal and J.C. Therriault. 1990. Simultaneous nitrogen and silicate deficiency of a phytoplankton community in a coastal jet-front. Mar. Biol., 104: 329-338.

Levasseur, M., M. Castonguay, E. Bonneau, F. Gregoire, S. Michaud and S.S. Bates. - 1994. Dynamics of paralytic shellfish toxin accumulation in Atlantic mackerel (Scomber scombrus). In: J.R. Forbes (ed.), Proceedings of the Fourth Canadian Workshop on Harmful Marine Algae, Can. Tech. Rep. Fish. Aquat. Sci., 2016: 21

Margalef, R. - 1978. Life-forms of phytoplankton as survival alternatives in an unstable environment. Oceanol. Acta, 1: 493-509.

Margalef, R., M. Estrada and D. Blasco. - 1979. Functional morphology of organisms involved in red tides, as adapted to decaying turbulence. In: L. Taylor and H.H. Seliger (eds.), Toxic dinoflagellates blooms. pp. 89-94. Elsevier, New York.

Martin, J.L. and A.W. White. - 1988. Distribution and Abundance of the Toxic Dinoflagellate Gonyaulax excavata in the Bay of Fundy. Can. J. Fish. Aquat. Sci., 45: 1968-1975.

Martin, J.L. and D. Richard. - 1996. Shellfish Toxicity from the Bay of Fundy, Eastern Canada: 50 Years in Retrospect. In: T. Yasumoto, Y. Oshima and Y. Fukuyo (eds.), Harmful and Toxic Algal Blooms. Intergovernmental Oceanographic Commission of UNESCO: 3-6

Medcof, J.C., A.H. Leim, A.B. Needler, A.W.H. Needler, J. Gibbard and J. Naubert. - 1947. Paralytic shellfish poisoning on the Canadian Atlantic coast. Bull. Fish. Res. Can., 75: 1-32. 
Medcof, J.C., N. Morin, A. Nadeau and A. Lachance. - 1966. Survey of incidence and risks of paralytic shellfish poisoning in the province of Quebec. Fisheries Research Board Canada MS Report (Biology), 886: 1-131.

Mertz, G., M.I. El-Sabh, D. Proulx and A.R. Condal. - 1988. Instability of a Buoyancy-Driven Coastal Jet: The Gaspé Current and Its St. Lawrence Precursor. J. Geophys. Res., 93: 68856893.

Pingree, R.D., P.M. Holligan, G.T. Mardell and R.N. Head. - 1976. The influence of physical stability on spring, summer, and autumn phytoplankton blooms in the Celtic Sea. J. Mar. Biol. Assoc. U.K., 56: 845-873.

Prakash, A. - 1967. Growth and toxicity of a marine dinoflagellate Gonyaulax tamarensis. J. Fish. Res. Bd. Canada, 24: 1289-1606.

Prakash, A., J.C. Medkof and A.D. Tennant. - 1971. Paralytic shellfish poisoning in eastern Canada. Bull. Fish. Res. Bd. Canada, 177: 87.

Reynolds, C.S. and T.J. Smayda. - 1998. Principles of Species Selection and Community Assembly in the Phytoplankton: Further Explorations of the Mandala. In: B. Reguera, J. Blanco, M. L. Fernandez and T. Wyatt (eds.), Harmful Algae. pp. 8-10. Intergovernmental Oceanographic Commission of UNESCO, Xunta de Galicia, Vigo,

Robineau, B., J.A. Gagné, L. Fortier and A.D. Cembella. - 1991. Potential impact of a toxic dinoflagellate (Alexandrium excavatum) bloom on survival of fish and crustacean larvae. Mar. Biol., 108: 293

Sevigny, J.M., M. Sinclair, M.I. El-Sabh, S. Poulet and A. Coote. 1979. Summer Plankton Distributions Associated with the Physical and Nutrient Properties of the Northwestern Gulf of St. Lawrence. J. Fish. Res. Bd Canada. 36: 187-203.

Shumway, S.E. and T.L. Cucci. - 1987. The effects of the toxic dinoflagellate Protogonyaulax tamarensis on the feeding and behavior of bivalve molluscs. Aquat. Tox., 10: 9-27.

Shumway, S.E., S. Sherman-Caswell and J.W. Hurst. - 1988. Paralytic Shellfish Poisoning in Maine: Monitoring a Monster. $J$. Shellfish Res., 7: 643-652.

Silvert, W. L.and D.W.S. Rao. - 1992. Dynamic model of the flux of domoic acid, a neurotoxin, through a Mytilus edulis population. Can. J. Fish. Aquat. Sci., 49: 400-405.

Silvert, W.L. and A.D. Cembella. - 1995. Dynamic modelling of phycotoxin kinetics in the blue mussel, Mytillus edulis, with implications for other marine invertebrates. Can. J. Fish. Aqua. Sci., 52(3): 521-531.

Sommer, H. and K.F. Meyer. - 1937. Paralytic shellfish poisoning. Arch. Path. 24(5): 560-598.
Tang, C. - 1980. Mixing and circulation in the Northwestern Gulf of St. Lawrence: a study of buoyancy driven current system. $J$. Geophys. Res., 85: 2787-2796.

Therriault, J.C., J. Painchaud and M. Levasseur. - 1985. Factors controlling the occurrence of Protogonyaulax tamarensis and shellfish toxicity in the St. Lawrence estuary: freshwater runnoff and the stability of the water column. In: A.W.W.D.M. Anderson and D.G. Baden (eds.), Toxic dinoflagellates. pp. 141-146. Elsevier, New York.

Trites, R.W. and K.F. Drinkwater. - 1991. The possible role of the surface circulation in the spread of PSP in the Western Gulf of St. Lawrence in 1988. In: J. C. Therriault (ed.), The Gulf of St. Lawrence: small ocean or big estuary? pp. 153-160. Can. Spec. Publ. Fish. Aquat. Sci.

Turgeon, J., A.D. Cembella, J.C. Therriault and P. Béland. - 1990. Spatial distribution of resting cysts of Alexandrium spp. in sediments of the lower St. Lawrence and the Gaspé coast (Eastern Canada). In: E. Graneli, B. Sundstrom, L. Edler and D.M. Anderson (eds.), Toxic marine phytoplankton. pp. 238-243. Elsevier, New York.

Turriff, N., J.A. Runge and A.D. Cembella. - 1995. Toxin accumulation and feeding behaviour of the planktonic copepod Calanus finmarchicus exposed to the red-tide dinoflagellate Alexandrium excavatum. Mar. Biol., 123: 55-64.

Twarog, B.M. - 1974. "Immunity" to paralytic shellfish toxin in bivalve molluscs. Proceedings of the Second International Coral Reef Symposium 1, Great Barrier Reef Committee, Brisbane, October 1974, 505-512

Twarog, B.M., T. Hidaka, and H. Yamaguchi. - 1972. Resistance to tetrodoxin and saxitoxin in nerves of bivalve molluscs. Toxicon, 10: 273-278.

Utermöhl, H. - 1931. Neue Wege in der quantitativen Erfassung des Plankton. Verh. Int. Ver. Limnol., 5: 567.

Vezina, A.F., Y. Gratton and P. Vinet. - 1995. Mesoscale PhysicalBiological Variability during a Summer Phytoplankton Bloom in the Lower St. Lawrence Estuary. Estuar. Coast. Shelf. Sci., 41: 393-411

White, A.W. - 1987. Relationships of environmental factors to toxic dinoflagellate blooms in the Bay of Fundy. Rapp. P.-V. Reun. Cons. Int. Explor. Mer, 187: 38-46.

Yentsch, C.M. and L.S. Incze. - 1981. Accumulation of Algal Biotoxins in Mussels. In: R. Lutz (ed.), Mussel culture in North America. pp. 223-246. Elsevier, New York.

Scient. ed.: D. Vaqué 